\title{
Egészségfejlesztés, betegségmegelőzés gazdasági elemzése
} Promoting Health, Preventing Disease - The economic case

Szerző: Járomi Éva $\square$

Országos Közegészségügyi Intézet

Beküldve: 2017.07.05.

doi: 10.24365/ef.v58i2.165

Kulcsszavak: gazdasági elemzés, egészségfejlesztés, betegségmegelőzés, beavatkozások, hatásosság

Keywords: Economic case, health promotion, disease prevention, intervention, efficiency

Napjainkban, az egészségfejlesztésbe és a nem fertőző megbetegedések megelőzésébe történő befektetés gazdasági elemzése jelentősebb, mint valaha. A krónikus, nem fertőző megbetegedések a halálozás és a megbetegedések fő okozói, amelyek jelentős része megelőzhető.

Az alább bemutatott könyv ${ }^{1}$ bizonyítékokat szolgáltat arra vonatkozóan, hogy a szakemberek és általuk a döntéshozók azonosítsák azokat a tényezőket, amelyek a kormányzatok pénzét hatékonyan alkalmazzák, különösen a betegség kialakulását megelőzően, még mielőtt az egészségügyi ellátás szükségessé válik.

Az egészségfejlesztés és a betegségmegelőzés világszerte kiemelt szerepet játszik az egészségpolitikában, mégis kevésbé alkalmazzák, részben azért mert nehézkes a beavatkozások bizonyítékainak összegyűjtése.

A kiadvány célja, hogy gazdasági szempontból közelítse meg a jobb minőségű egészségfejlesztés és betegségmegelőzés kihívásait a döntéshozók, szakemberek és tudósok széles körét megszólítva. A krónikus nem fertőző megbetegedések, úgy mint például a szív- és érrendszert érintő megbetegedések és a diabétesz, a halálozások fő okozói világszerte. A fenti betegségekhez kapcsolódó betegségterhek közül néhány elkerülhető lenne hatékony egészségfejlesztéssel és a betegségmegelőzéssel. A legfontosabb kérdés az, hogy vajon rendelkezésre áll-e a fenti beavatkozásokhoz kapcsolódó gazdasági elemzés.

A kötet az EVSZ (Egészségügyi Világszervezet), az a GEFSZ (Gazdasági Együttmúködési és Fejlesztési Szervezet) ismertebb nevén OECD (The Organisation for Economic Co-operation and Development) és az Egészségügyi Rendszerek és Szakpolitikák Európai Megfigyelőközpontjának közös munkájaként jött létre. Megjelenésével a bizonyítékokon alapuló egészségpolitikák megvalósulásához kívánnak hozzájárulni, az európai egészségügyi rendszerek átfogó elemzése útján. A kiadvány első fejezete áttekinti, hogy a gazdaság hogyan járulhat hozzá azon folyamat megértéséhez, amely által a krónikus megbetegedések kialakulnak, és amelyek a döntéseket és viselkedéseket meghatározzák ezalatt az időszak alatt. Tartalmazzák az alapvető fogalmakat és elméleti vitákat, ideértve a beavatkozások gazdasági logikáját, a módszerek gyakorlati illusztrációját, valamint a költségek és eredmények mérését, amelyeket általában a gazdasági elemzésekben alkalmaznak.

Az egyik fő következtetés az, hogy a különböző piaci kudarcok olyan gazdasági okokat képeznek a kormányzat számára, amelyek az egészségfejlesztési és 
betegségmegelőzési beavatkozások megvalósítására ösztönzik, mindezt a társadalmi jólét javításának egy alternatívájaként. A viselkedés okozta nem megfelelő egészségi állapot költségeket vonhat maga után, amelyek elsősorban nem azoknál az egyéneknél keletkeznek, akik hasonló viselkedéssel bírnak. A külső gazdasági hatások összefüggnek azok járulékos hatásaival, melyek túlmutatnak az egyénen. Ezek érintik a családokat, és megterhelik a közszolgáltatásokat is. Például a passzív dohányzás ártalmaival, az alkohol abúzussal összefüggő erőszakos és rendellenes viselkedéssel, valamint a felelőtlen vezetésből eredő közlekedési balesetekkel. Egy szabad piacon az árak valószínúleg nem tükrözik ezeket a hatásokat.

Valószínűsíthető, hogy a fogyasztók kevés rendelkezésre álló információval bírnak ahhoz, hogy racionális és hatékony/eredményes döntéseket hozzanak. A bizonytalanság és a félreértés gyakran súlyosbítja a különböző életmódbeli döntések egészségügyi előnyeit és káros hatásait. Emellett az emberek nem minden esetben viselkednek racionálisan, amikor döntéseket hoznak. Néha az addiktív viselkedésük vagy viselkedés-formájuk, úgy, mint például a dohányzás vagy a játékszenvedély miatt, néha azért, mert "rövidlátóak", a jelen egészségtelen életmódját, az "élvezetet" választják, elutasítva a jövőbeli kockázatot. Illetve lehetséges, hogy szándékában áll, de nem sikerül megváltoztatnia a jövőbeli viselkedését. A döntést/választást mindemellett befoIyásolja például a kortársak nyomása, vagy hogy melyik terméket reklámozzák vagy helyezik ki az üzletek polcain.

A könyv fő célja a speciális viselkedésből eredő kockázati faktorok kezelésének gazdasági bizonyítékainak áttekintése, úgy mint a dohányzás, a túlzott alkohol fogyasztás, a fizikai aktivitás hiánya/mozgásszegény életmód és az egészségtelen táplálkozás, valamint a környezethez kapcsolódó kiválasztott kockázati tényezők, úthálózat, lelki egészség és jóllét. Keresztmetszeti témája továbbá a dokumentumnak az egészség kiválasztott társadalmi meghatározóit célzó beavatkozások bemutatása, különös tekintettel az oktatásra és a korai intervencióra. A szakpolitikai beavatkozások és a fő megvalósítási problémák elosztási hatásai pedig egy következő fejezetben jelennek meg.
A kiadvány kulcsüzenete szerint jelentős bizonyítékok állnak rendelkezésre minden vizsgált tématerület költség-hatékonyságáról. Ezek közül számos területen az intézkedésekhez kapcsolt költségvetési politikához és az egészséggel kapcsolatos információkhoz való hozzáférés javítása sokkal költség-hatékonyabb, mint bármely más elszigetelt intézkedés. A dohányzás megelőzés esetében például, annak megadóztatása az egyetlen és leginkább költséghatékony intézkedés. De még ennél is nagyobb egészséghaszon érhető el, ha ez kombinálható lenne a dohányfüst-mentes környezetet érintő szabályozással, a reklámozás tilalmával, a figyelmeztető címkézés alkalmazásával, a tömegkommunikációs kampányok megvalósításával, melyeknek még mindig kedvezőbb a költséghatékonysága, mint egyegy elszigetelt tematikus média kampánynak.

A hatásosnak bizonyuló alkohol-politika pedig magában foglalja a kiskereskedelmi forgalomban lévő alkoholhoz való hozzáférés korlátozását, az alkohol reklámozásának tilalmát, amely vonatkozik a közösségi médiára is, az adók emelését és az alkohol egységenkénti minimális árának bevezetését. Sokkal költségesebb, de még mindig költség-hatékonyabb intézkedés a kockázatos ivók számára történő rövid tanácsadás, kiegészülve az ittas vezetéssel kapcsolatos jogi szabályozással, valamint a szondáztatással, az alkohollal összefüggő megbetegedésekhez kapcsolódó kezelésekkel. A médiakampányok, a saját és iskolai egészségfejlesztési programok viszont nem tűnnek költség-hatékonynak. Fentiek alapján a kiadvány megállapítása szerint olyan stratégiára van szükség, amely a beavatkozások kombinálásán alapul, mert nagy valószínúséggel nagyobb egészségnyereséget eredményez, miközben megőrzi költség-hatékonyságát.

Arra szintén van bizonyíték, hogy bizonyos intézkedések növelik az emberek táplálkozásának minőségét. Az élelmiszerek magas só, cukor és zsírtartalmára kiszabott adó következetesen költségkímélő intézkedéseknek számít, bár ez egyre inkább csökkenni látszik. Körültekintő tervezésre van szükség annak érdekében, hogy elkerüljük a nem kívánatos helyettesítők hatását - például az egészséges ételeket és italokat, vagy a hátrányos helyzetű fogyasztókat célzó támogatások összekapcsolásával. A feldolgozott élelmiszerek sótartalmának csökkentését célzó szakpolitikák számos tanulmány szerint kedve- 
zőbb költség-hatékonysággal bírnak, habár kevés bizonyíték áll rendelkezésre az egyéb élelmiszerek összetételét érintő átalakítások (pl. transzzsírsavtartalom) hatékonyságára vonatkozóan. A szakpolitika további célja például a gyümölcsök és a zöldségek hozzáférhetőbbé tétele az iskolákban, mérsékelten pozitív hatással bírhat. Az élelmiszercímkézési minták költség hatékonyak lehetnek, bár kevés tanulmányban vizsgálták őket. Néhány kutatás támogatja az élelmiszerek gyermekeknek szóló reklámozásának korlátozásait, amelyek hatékonyabban és jobban múködnek abban az esetben, amikor kötelező jelleggel valósítják meg, mint az ön-szabályozáson keresztül. A fizikai aktivitás népszerűsítése a tömegkommunikációs kampányokon keresztül költség-hatékony és relatíve olcsó, habár, az egészségnyeresége alacsonyabb a célzottabb intervenciót nyújtó programokénál (pl. a munkahelyi színtéren).

A közlekedési rendszer változása valamint a fizikai aktivitási lehetőségek hozzáférésének növekedése a tágabb környezetben, mint pl. kerékpár tárolók biztosítása, szintén potenciális előnyt jelent. Emellett azonban további körültekintő elemzésre van szükség, hogy megállapítsák ezen intézkedések megfizethetőségét és a megvalósíthatóságát. Általánosságban elmondható, hogy a beavatkozások, amelyek a magas kockázatú felnőtt populációt és egyéneket célozzák, nagyobb hatást érnek el a rövidebb időkeret alatt, mint a gyermekeket és fiatal felnőtteket célzó programok.

A mentális egészség előmozdítására és a betegségmegelőzésre vonatkozó gazdasági elemzések biztatóak. A bizonyítékok azt sugallják, hogy nagyobb a megtérülése az egy életen átívelő intézkedéseknek, a korai beavatkozásnak gyermekkorban, a társas és érzelmi tanulás, megküzdési képességek és a szülőgyermek kötődés esetében. Gazdasági érvek támogatják a munkahelyi egészségfejlesztési beavatkozásokat, a jobb fizikai állapot elősegítése érdekében, amely a munkavállaló hasznára válik. A költség-hatékony prevenciós programok a lakosság magas kockázatú csoportjait, beleértve az elszigetelt idős embereket és kismamákat is célozhatják.

A közlekedési balesetek megelőzését célzó beavatkozások, ideértve az utak kialakításnak módosítását, a városi közlekedési forgalom mérséklését, valamint kamera és trafipax telepítését végrehajtó progra- mok, hangzatos/erőteljes bizonyítékok által kerülnek támogatásra, különösen akkor, ha magas kockázatú területeken alkalmazzák őket. A jó minőségú utak, felelősségteljes viselkedést elősegítő szabályozásának aktív végrehajtása, beleértve az ittas vezetés csökkentését célzó intézkedéseket, szintén költség-hatékonyak lehetnek. Számos gazdasági tanulmány támogatja a környezeti kémiai veszélyek elleni küzdelmet: például a Vegyi Anyagok Regisztrálásáról, Értékeléséről, Engedélyezéséről és Korlátozásáról (REACH) szóló 2007-es rendelet, amelynek része az ólom-alapú festék eltávolítása, széntüzelésű erőművekből származó higanyszennyezés csökkentése, valamint a jármúforgalom mérséklése (pl. torlódási díj-rendszerek). Ezek az intézkedések csökkentik az egészségügyi ellátási és egyéb gyermekkori asztmával, bronchitisszel, valamint a korai légzőrendszert érintő megbetegedésekkel összefüggő költségeket.

További kulcsüzenet, hogy az adekvát megvalósítás és értékelés nélkülözhetetlen számos áttekintett intézkedés költség-hatékonysági potenciáljának realizálásához. További lépések szükségesek az egészségügyi szektoron kívül megvalósuló intézkedések elősegítésére. Ezek magukban foglalhatják a szektorok közötti önkéntes és a kötelező partnerséget is, amely a befektetések pénzügyi kockázatainak és előnyeinek megosztásával jár, a szúk ágazat-specifikus érdekek leküzdése érdekében.

Végül, létfontosságú, hogy az egészségfejlesztés és a betegségmegelőzés előnyeivel kapcsolatos elvárások reálisak maradjanak. Az egészségügyi kiadások csökkentése nem tekinthető a megelőzés egyetlen céljának. A gazdasági elemzést ugyanúgy kell elkészíteni, mint más egészségügyi beavatkozások esetében. Ez a kiadvány pedig azt hivatott előre jelezni, hogy a megelőzés és az egészségfejlesztés hozzájárulhat az egészség és a jólét javításához, amelynek költség-hatékonysága ugyanolyan jó vagy jobb, mint az egészségügyi ellátás számos elfogadott formája.

Hazánkban a fent bemutatott kiadványhoz hasonló szakirodalom, amely az egészségfejlesztést gazdasági szempontból közelíti meg, csupán korlátozottan áll rendelkezésre. Vokó-Kaló nagy jelentőséggel bíró megközelítése azonban némileg eltér a fent ismertetett könyv nézőpontjától. Szerintük a szakem- 
berek jelentős része a prevencióban látja az egészségügy finanszírozási problémáinak egyik fő potenciális megoldási lehetőségét. Azonban a megelőzés egészség-gazdaságtana ennél jóval összetettebb. Az eredményes betegségmegelőzés hosszabb és jobb egészségben megélt életévekkel jár. A krónikus nem-fertőző megbetegedések megelőzése által a megbetegedések kialakulása és az általuk okozott halálozás időpontja későbbre tolódik. A megnövekedett élettartam miatt azonban olyan betegségek is bekövetkeznek, amelyek a korai halálozás esetén nem fordultak volna elő. Például, ha valaki 60 évesen meghal emlórákban, akkor 75 évesen nem kerülhet combcsonttöréssel kórházba. Modellezve 20 évre az egészséges életmódúak, az elhízottak és a dohányosok várható életútját, a várható élettartam és a teljes élethosszra jutó egészségügyi kiadás is az egészséges életmódúak körében volt a legnagyobb és a dohányosok esetében pedig a legkisebb. A szerzők állítása szerint, ugyanis a szakirodalomban nagyon kevés olyan, a nem-fertőző megbetegedések megelőzésére irányuló beavatkozást találni, amely hosszú távon az egészségügyi kiadások csökkenésével járna. Paradox módon, minél eredményesebben növeli egy beavatkozás a várható élettartamot, annál jobban növeli a teljes élethosszra jutó egészségügyi kiadásokat. ${ }^{2}$

Ily módon a megelőzés gazdasági egyenlege az egészségügyi kiadásokat nézve nem feltétlenül jár az egészségügyi kiadások csökkenésével. Fontos hangsúlyozni, hogy a prevenciós és egészségfejlesztési beavatkozások költséghatékonysági elemzéseiben a számba vett nyereségek és költségek körének meghatározásán túl számos - az eredményeket alapvetően befolyásoló - technikai, módszertani kérdés merül fel. Ilyen például a gazdasági elemzés választott időtávja vagy az alkalmazott diszkontráta'. A mindenkori vizsgálatok eredményeinek értelmezésekor tehát különösen fontos annak módszertanát is figyelembe venni. ${ }^{2}$

\section{HIVATKOZÁSOK}

\footnotetext{
${ }^{1}$ David McDaid et al. (szerk.) Promoting Health, Preventing Disease - The Economic Case, World Health Organization 2015 (acting as the host organization for, and secretariat of, the European Observatory on Health Systems and Policies)

${ }^{2}$ Vokó Zoltán, dr. - Kaló Zoltán, dr.: Prevenció - kiadások - hatékonyság, Egészségügyi Gazdasági Szemle 50. évfolyam 1. szám, 2012. március http://www.weborvos.hu/adat/files/2012 junius/egsz 2012 1.pdf (Elérve: 2017. július 24.)
}

\footnotetext{
i Az egészség-gazdaságtani elemzéseknél az időpreferenciát, illetve az erőforrások haszonáldozati költségét diszkontálás segítségével kell figyelembe venni. Mivel az egészségügy területén hozott döntések társadalmi hatása jelentős, nagyban hozzájárulnak a közösség jólétéhez, ezért a jövőbeli hatásuk számszerűsítésénél nem megfelelő a piaci megtérülési ráták használata. A társadalmi diszkontráta a társadalomnak a jelen és a jövőbeli jóléte közötti átváltás értékelését tükrözi (Dankó et al. A társadalmi diszkontráta meghatározása Magyarországon a Ramsey-formula alkalmazásával 2017. január http://www.healthware.hu/files/public/SDR becslese modszertan 2010.pdf)
} 